\title{
Evaluation of hypo-osmotic swelling test and supra vital staining technique as indicators for donkey semen freezability
} \author{
xeira', José de Oliveira Carvalho², Margot Alves Nune Dode², Ivo Pivato' and Sven Budik ${ }^{3}$ \\ 1 Animal Reproduction, College of Agronomy and Veterinary Medicine, University of Brasília, Brasília, Brazil \\ 2 Laboratory of Reproduction - Embrapa Recursos Genéticos e Biotecnologia, Brasília, Brazil \\ ${ }^{3}$ Artificial Insemination and Embryo Transfer, Veterinary University Vienna, Vienna, Austria
}

Rodrigo Arruda de Oliveira', Aline Batista Silva Teixeira', Tatiana Almeida Pignataro', Mariane Leão Freitas ${ }^{7}$, Heitor Castro Alves Tei-

\begin{abstract}
Summary: Reproductive biotechnologies such as cooling and freezing semen are employed in order to obtain genetic enhancement in domestic animal breeds. However, cryopreservation of donkey semen, as in several other domestic mammalian species, has not yet reached a standard procedure that provides satisfactory and repeatable results, as in bulls. Despite there are over 43 million donkeys worldwide, there are only few studies about donkey semen preservation. The aim of this study was to evaluate the predictive potential of hypo-osmotic test and the supra vital staining in raw semen to be used as indicators for donkey semen freezability. Ejaculates were collected twice per week from 10 fertile donkey stallions. Volume, appearance (color and density), concentration, total motility, morphology, sperm viability (supra vital staining - eosin-nigrosin-EN) and plasma membrane integrity (hypo-osmotic swelling test - HOST) were evaluated in raw semen. After dilution the samples were centrifugated and sperm pellets were resuspended in a freezing extender to a concentration of $50 \times 10^{6}$ cells $/ \mathrm{mL}$. Aliquots were packed into $0.5 \mathrm{~mL}$ straws and placed in the refrigerator $\left(5^{\circ} \mathrm{C}\right)$ for $20 \mathrm{~min}$. Subsequently these straws were kept above liquid nitrogen for $20 \mathrm{~min}$, then plunged into nitrogen and stored in a holding tank. Post-thaw analyzes consisted in computerized analysis of sperm movement characteristics, sperm viability (EN), plasma membrane integrity (HOST and fluorescent probe) and acrosome membrane integrity using fluorescent probe. High correlation was found between EN (0.93) and HOST (0.69) in raw semen when compared with total motility after frozen-thawed semen. Low correlation was found between EN and HOST when compared with plasma and acrosomal membrane integrity in post-thawed with fluorescent probes. Since sperm motility is one of the key parameters to evaluate the quality of frozen semen, hypo-osmotic test and supra vital staining can be considered good predictive indicators in raw semen for donkey semen freezability.
\end{abstract}

Keywords: Equus Asinus, cryopreservation, eosin-nigrosin, plasma membrane integrity, semen, reproduction

Citation: Arruda de Oliveira R., Batista Silva Teixeira A., Almeida Pignataro T., Freitas M. L., Castro Alves Teixeira H., de Oliveira Carvalho J., Alves Nune Dode M., Pivato I., Budik S. (2017) Evaluation of Hypo-osmotic swelling test and supra vital staining technique as indicators for donkey semen freezability. Pferdeheilkunde 33, 159-164; DOI 10.21836/PEM20170208

Correspondence: Prof. Rodrigo A. de Oliveira, College of Agronomy and Veterinary Medicine, Animal Reproduction, University of Brasília, Instituto Central de Ciências, Ala Sul, Asa Norte, 70910-900 Brasília/DF/Brazil; e-mail: rodrigoarruda@unb.br

\section{Introduction}

There is a great interest in using donkey stallions for hybrids production (mules), to be used in large cattle farms and even for leisure. One of the most popular donkey breed to do this crossing is the Pêga donkey jacks, since they have and give docility and comfortable gait for their offspring (Canisso et al. 2010).

Reproductive biotechnologies such as cooling and freezing semen are employed in order to obtain genetic enhancement in domestic animal breeds. However, cryopreservation of donkey semen, as well as in several other domestic mammalian species, has not yet reached a standard that provides satisfactory and repeatable results, as in bulls (Vidament et al. 2009). In addition, the number of studies related to donkey frozen semen is still limited. Thus, most of the time equine semen protocols are used as a standard, because among the domestic animals it is the closest relative to the donkey and one of the most studied species (Oliveira et al. 2016).

The cryopreservation process causes damage to the cell plasma membrane which can result in changes in membrane phospholipids, and modifications on cell permeability (Amann and Picket 1987, Flores et al. 2008). At low temperatures, changes occur in accuracy of the sodium-potassium pump. With the reduction of potassium influx, extracellular potassium becomes larger, and sodium efflux reduces. As a result destabilization of the plasma membrane and opening of calcium channels will occur. Calcium influx can cause the activation and lysis of phospholipids, leading to changes in plasma membrane permeability which may cause cell death (Amann and Picket 1987). Therefore, cryopreservation submits the sperm cell to a stress which causes changes in the plasma membrane and consequently decreases or causes the loss of cell function. These changes vary between species and breeds.

Hence it is necessary to implement tests that can be used in raw semen in order to predict changes after thawing, such as total motility and others that may evaluates plasma membrane integrity. Among those tests, there are two simple, low cost and convenient tests to be carried out: hypo-osmotic swelling test (HOST) and supra vital staining (Live/Dead) with eosin and nigrosine. While vital stains are used to evaluate if the plasma membrane is physically damaged, the HOST is used to evaluate the membrane biochemical activity (Jeyendran et al. 1984, Vidament et al. 1998). 
The hypo-osmotic swelling test evaluates the functional integrity of the plasma membrane. Spermatozoa are placed in a hypo-osmotic solution and because of the difference in osmolarity, the solution enters into the cell until an osmotic equilibrium is reached with the extracellular medium. Water influx will increase the volume of sperm cells making the membrane turgid. The plasma membrane of the tail, known to be more sensitive to this test, will swell due to the increase of water. When this reaction occurs, cell plasma membrane is intact (Neild et al. 1999).

The eosin-nigrosin staining evaluates the structural integrity of the plasma membrane (viability). In this test two dyes are used in which eosin will stain cells by binding the nucleic acids of the spermatozoa with no membrane integrity, showing a difference between living sperm from dead sperm. Afterwards, nigrosine enhances the background contrast, making it easier to differentiate the two cell populations. Hence, sperm with damaged membranes will be stained, while spermatozoa with intact membranes will not be stained (Dott and Foster 1972).

Experiments that correlate overall motility, viability and plasma membrane integrity with quality after thawing or even pregnancy rates have been controversial. However, most of these studies have been conducted in bulls (Brito et al. 2003), rams (Gundogan et al. 2010) and stallions (Vidament et al. 1997, Vidament et al. 1998, Neild et al. 1999, Oldenhof et al. 2015), therefore studies are needed to be done in donkey species, in order to evaluate the correlation of these tests with sperm quality after cryopreservation. Finally, this study aimed to investigate if hypo-osmotic test and eosin-nigrosine staining could be used in raw semen as a freezability prediction for donkey semen.

\section{Material and methods}

\section{Animals}

Experiments were conducted on a farm in Brazil, Mato Grosso state, $\left(14^{\circ} 18^{\prime} 23^{\prime \prime S} 50^{\circ} 51^{\prime} 40^{\prime \prime} \mathrm{O}\right)$. The weather of this region is Koppen Aw, indicating dry winter and rainy summer. Semen from 10 jacks of Pêga Breed, between the ages of 4 and 12 years, was collected once a day for 7 days to stabilize extra gonadal reserve and daily sperm output. After one week of rest period ejaculates were collected two times per week from each of 10 fertile Pêga Jacks using the Colorado model (Equine Artificial Vagina; ARS, Chino-CA, USA) artificial vagina, with a total of 20 ejaculates obtained. Semen samples were collected in a plastic bottle and filtered with a nylon filter immediately after collection to create gel-free semen. Only ejaculates with more than $60 \%$ of motility were used for cryopreservation.

After collection and analysis, the sperm-rich fraction (gel-free) was diluted 1:1 in a skimmed milk-glucose extender with penicillin G procaine (Botusêmen, Biotech Botucatu, São Paulo, Brazil). After dilution, samples were centrifugated at $600 \mathrm{~g}$ for 10 minutes and sperm pellets were resuspended in a freezing extender (Botucrio, Biotech Botucatu, Botucatu, SP, Brazil) to a concentration of $50 \times 10^{6}$ cells $/ \mathrm{mL}$. Aliquots were packed into $0.5 \mathrm{~mL}$ straws and placed in a stainless steel sup- port and kept inside the refrigerator $\left(5^{\circ} \mathrm{C}\right)$ for $20 \mathrm{~min}$. Subsequently, these straws were kept of $6 \mathrm{~cm}$ above liquid nitrogen for $20 \mathrm{~min}$ in an isotherm box, then plunged into liquid nitrogen and stored in a liquid nitrogen holding tank.

\section{Seminal analysis}

Raw semen

To evaluate total motility (0-100\%) and strength (0-5), a $10 \mu \mathrm{L}$ drop of semen was placed between a previously heated $\left(37^{\circ} \mathrm{C}\right)$ slide and coverslip visualized under a contrast phase optical microscope at $200 \times$ magnification. Strength was expressed as the speed at which the spermatozoa move in the field. The result was expressed on a scale of $0-5,0$ being no motion and 5 intense motion (CBRA 2013).

Sperm concentration was evaluated by counting in hematology chamber (Neubaver) after semen dilution (1:20) in buffered formalin citrate. This evaluation was performed under an optical microscope in $200 \times$ magnification (CBRA 2013, Brito et al. 2016).

To evaluate the morphology the humid chamber was used and 200 spermatozoa per sample were counted in $1000 \times$ magnification in phase contrast. The percentages of morphological abnormalities were grouped and classified as major, minor and normal sperm defects (CBRA 2013).

For the viability evaluation, the supra vital eosin-nigrosin staining technique (LIVE/DEAD) was used. Equal volumes $(20 \mu \mathrm{L})$ of semen and stain were mixed and transferred to a preheated $\left(37^{\circ} \mathrm{C}\right)$ microscope slide and smeared by sliding a cover slip and examined directly. Samples were evaluated by optic microscopy (magnification $1000 \times$ ). Two hundred sperm cells were counted per sample and unstained cells were classified as viable (Dott and Foster 1972).

To evaluate sperm plasma membrane integrity, the hypoosmotic swelling test (HOST) was used by incubation of $100 \mu \mathrm{L}$ of raw semen in $1.0 \mathrm{~mL}$ of a sucrose solution of $100 \mathrm{mOsm} / \mathrm{L}$ incubated in water bath at $37^{\circ} \mathrm{C}$ for $30 \mathrm{minu}$ tes. After this time, $20 \mu \mathrm{L}$ of this solution were analyzed in a humid chamber, using phase-contrast microscopy at $1000 \times$ magnification. A total of 200 spermatozoa were counted and those considered swollen (coiled) were determined as having membrane integrity, after the subtraction of tail alterations percentage found in the morphologic evaluation (Melo and Henry 1999).

\section{Post thaw analysis}

The straws were thawed at $37^{\circ} \mathrm{C}$ for $30 \mathrm{~s}$ after one week of storage in a liquid nitrogen holding tank. The computerized analysis of sperm movement characteristics was performed with an Ivos-Ultimate 12 unit 3, previously adjusted for equine semen. Three fields were selected for analysis. Measured parameters included total motility (\%), progressive motility $(\%)$, average path velocity (VAP, $\mu \mathrm{m} / \mathrm{s})$, curvilinear velocity $(\mu \mathrm{m} / \mathrm{s})$, amplitude of lateral head displacement $(\mu \mathrm{m})$, beatcross frequency $(\mathrm{Hz})$, linearity (\%), and straightness (\%). 
System parameters for computerized assisted semen analysis were: 45 frames acquired at 60 frames/s; minimum contrast, 70; minimum cell size, 4 pixels; VAP cut-off, $20 \mu \mathrm{m} / \mathrm{s}$; and VAP cut-off for progressive cells, $50 \mu \mathrm{m} / \mathrm{s}$ and straightness $60 \%$; straight line velocity cutoff, $0 \mu \mathrm{m} / \mathrm{s}$. The slow cells were considered static. A 10 I drop of each sample was placed on a preheated $\left(37^{\circ} \mathrm{C}\right)$ Makler counting chamber (10 $\mu \mathrm{m}$ depth).

To evaluate sperm plasma membrane integrity, the 6-carboxyfluorescein diacetate and propidium iodide fluorescent dyes (CFDA/PI) were used, in accordance with the description by Harrison and Vickers (1990). The acrosomal integrity was evaluated by the conjugation of fluoresceine isothiocyanate with peanut agglutinin lectin (FITC/PA) and propidium iodide (Klinc and Rath 2007).

Structural (eosin-nigrosin) and functional (hypo-osmotic) assays for membrane integrity in post thaw analyzes were also performed.

\section{Statistical analysis}

Data analysis was performed using the R Core Team, 2013 and Prophet 5.0 procedure to determine if the experimental error of variables had normal distribution for variance probability and homogeneity. Since the studied variables did not present normal distribution, a non-parametric test, KruskalWallis $\mathrm{H}$ test (WinStat module; Microsoft) was used to compare plasma membrane integrity tests. The correlation of eosin-nigrosine and hypo-osmotic tests with plasma membrane integrity, acrosome membrane integrity and total motility of the raw semen was evaluated with Pearson correlation where the correlation of eosin-nigrosine and hypo-osmotic with plasma membrane integrity were log transformed for normalization of the data. Shapiro-Wilk test was used to assess the normality of the data. A level of $95 \%$ probability in all the tests used $(P<0.05)$ was assumed.

\section{Results}

The values obtained for raw semen (volume, total motility, strength, viability (EN), plasma membrane integrity (HOST) and sperm morphology) are summarized in Table 1. For raw semen values for total motility $(81.0 \pm 13.2 \%)$; EN $(84.7 \pm 9.9 \%)$ and HOST $(54.9 \pm 23.3 \%)$ were obtained. The average sperm concentration was $317.9 \pm 26 \times 10^{6}$ spermatozoa/mL.

The results from post-thawed computerized analysis of sperm movement characteristics (CASA) are presented in Table 2, with a total motility mean of $50.4 \pm 22.7$ and progressive motility of $12.2 \pm 8.1$.

The correlation analysis of hypo-osmotic test and eosinnigrosin staining carried out in raw semen with total motility, plasma membrane and acrosome membrane integrity with fluorescent probes of the post thawed semen are shown in Table 3. There was a high correlation between EN (0.93) and HOST (0.69) in raw semen when compared with total motility after frozen semen. Low correlation was found between EN and HOST when compared with plasma and acrosome membrane integrity in post-thawed with fluorescent probes.

When the comparison of these three tests for the evaluation of post-thawed plasma membrane integrity was done (EN, HOST and fluorescent probe with CFDA), there was no difference between HOST and CFDA/PI (P>0.05), this means that

\begin{tabular}{|c|c|c|c|c|c|c|c|}
\hline \multirow{2}{*}{\multicolumn{8}{|c|}{$\begin{array}{l}\text { Table } 1 \text { Results of raw d } \\
\text { (\%; EN), plasma membrane in } \\
\text { minor defect (\%; MINDEF). } \\
\text { Vol Mot }\end{array}$}} \\
\hline & & & & & & & \\
\hline & & & & & $\mathrm{N}$ & MADEF & MINDEF \\
\hline $\begin{array}{c}55.0 \\
\pm 33.8\end{array}$ & $\begin{array}{c}81.0 \\
\pm 13.3\end{array}$ & $\begin{array}{c}4.3 \\
\pm 0.7\end{array}$ & $\begin{array}{r}84.7 \\
\pm 9.9\end{array}$ & $\begin{array}{c}54.9 \\
\pm 23.3\end{array}$ & $\begin{array}{r}76.9 \\
\pm 11.9\end{array}$ & $\begin{array}{c}12.1 \\
\pm 9.1\end{array}$ & $\begin{array}{r}10.3 \\
\pm 6.0\end{array}$ \\
\hline
\end{tabular}

Table 2 Results of computerized assessment analyses of donkey post-thaw semen ( $=10)$ : total motility (\%), progressive motility (\%), straightness (\%; STR), linearity (\%; LIN), average path velocity $(\mu \mathrm{m} / \mathrm{s}$; VAP), progressive linear velocity $(\mu \mathrm{m} / \mathrm{s}$; VSL), curvilinear velocity $(\mu \mathrm{m} / \mathrm{s}$; VCL), amplitude of lateral head displacement $(\mu \mathrm{m} ; \mathrm{ALH})$ and beat cross frequency $(\mathrm{Hz} ; \mathrm{BCF})$.

\begin{tabular}{|c|c|c|c|c|c|c|c|c|}
\hline Total Motility & Progressive Motility & STR & LIN & VAP & VSL & VCL & $\mathrm{ALH}$ & $\mathrm{BCF}$ \\
\hline $\begin{array}{c}50.4 \\
\pm 22.7\end{array}$ & $\begin{array}{r}12.2 \\
\pm 8.1\end{array}$ & $\begin{array}{r}81.2 \\
\pm 7.6\end{array}$ & $\begin{array}{l}49.3 \\
\pm 7.0\end{array}$ & $\begin{array}{l}46.0 \\
\pm 6.2\end{array}$ & $\begin{array}{l}37.4 \\
\pm 3.9\end{array}$ & $78.5 \pm 12.7$ & $\begin{array}{c}4.6 \\
\pm 1.4\end{array}$ & $\begin{array}{l}43.1 \\
\pm 2.1\end{array}$ \\
\hline
\end{tabular}

Table 3 Correlation analysis ( $r$ values) between eosin-nigrosin staining (EN) and hypo-osmotic (HOST) tests results using raw semen of donkeys $(n=10)$ and the results of total motility (TMOT), plasma membrane (PMI) and acrosome membrane integrity (AMI) of the post thawed semen using fluorescent probes.

\begin{tabular}{lccc}
\hline & TMOT $(p d)$ & PMI $(p d)$ & AMI (pd) \\
\hline HOST(rs) & 0.69 & 0.13 & 0.17 \\
EN (rs) & 0.93 & 0.13 & 0.11 \\
\hline
\end{tabular}

Pearson correlation $(P<0.05)$. Raw semen (rs); Post-thawed (pd)
Table 4 Post-thawed analyses of donkeys' semen $(n=10)$ regarding plasma membrane integrity: Comparison between eosinnigrosin (\%; EN), hypo-osmotic test (\%; HOST) and fluorescent probe (\%; CFDA/PI) results.

\begin{tabular}{ccc}
\hline EN & HOST & CFDA/PI \\
\hline 50.9 & 31.2 & 32.2 \\
\pm 21.4 & \pm 17.0 & \pm 13.7 \\
\hline
\end{tabular}

ANOVA: Kruskal-Wallis Test. Different letters in the same row are indicative of difference $(\mathrm{P}<0.05)$. 
HOST has the same accuracy than fluorescence probe to evaluate plasma membrane integrity (Table 4). Regarding post-thaw sperm, plasma membrane integrity with CFDA/PI was $32.2 \pm 13.7 \%$ and acrosome membrane integrity with FITC/PA was $30.1 \pm 14.8 \%$.

\section{Discussion}

The use of frozen thawed semen in donkeys is not as common as it in equines, due to several reasons: Small number of "good freezing" animals with current horse protocols applied to donkeys and the low pregnancy rates obtained with this type of semen (Vidament et al. 2009, Oliveira et al. 2016). To the best of our knowledge, no information about the correlation of these simple tests as indicators for donkey semen freezability has been available so far.

There was a high positive correlation between HOST and EN in raw semen with post-thaw total motility. As we known motility has a high correlation with fertility, which makes the execution of these two tests on the pre-freezing breeding soundness exam so important. Neild et al. (2000), also evaluated if HOST in raw semen could be correlated with stallion fertility and concluded that there is a good correlation with HOST progressive motility of the raw semen $(r=0.82, P=0.0001)$. Despite HOS test was not correlated with the percentage of pregnant mares $(r=0.08, P=0.75)$, there was a tendency to correlate with the number of services per pregnancy $(r=-0.40 ; P=0.08)$. Thus, HOS test could be used as an additional method to evaluate the fertility of fresh semen in stallions.

Neild et al (1999) compared the correlation between progressive motility and HOST in raw and in frozen-thawed stallion semen, and observed a high correlation between progressive motility and HOST $(P<0.05)$ both in fresh $(r=0.75)$ and frozen-thawed semen $(r=0.57)$. However Oldenhof et al. (2015) observed that pre-freeze percentages of membrane-intact spermatozoa after exposure to hypotonic stress showed a weak correlation with sperm motility after cryopreservation and conclude that studies on pre-freeze tolerance towards hypotonic stress cannot be used to predict sperm cryosurvival rates for individual stallions.

Our HOST results obtained from raw semen were similar to found by Canisso et al. (2011) in donkeys, which obtained values between 44.1 to $57.9 \%$. Moreover, there was no difference $(P>0.05)$ in post-thawing plasma membrane integrity when HOST or CFDA/PI was used. Therefore, hypo-osmotic test has the same accuracy as fluorescence probes regarding the plasma membrane integrity (Table 4).

The percentage of sperm with plasma membrane integrity was higher $(\mathrm{P}<0.05)$ in post-thawed sperm with $\mathrm{EN}$ staining than with HOST and CFDA/PI. This result is in agreement with findings from Chalah and Brillard (1998) and Merkies et al. (2000), indicating that EN stain may underestimate the proportion of sperm with damaged membranes when compared to $\mathrm{PI}$ stain, used alone, or in combination with CFDA/PI. According to Brito et al (2003), some sperm cells may have a nonfunctional membrane that still have the ability to prevent eosin molecules from entering the cell, but are weak enough to not express the increased pressure by HOST observed in normal cells. Therefore, HOST could be considered to be a more accurate plasma membrane test to predict the fertilizing capacity of a semen sample.

Our results from raw semen (Table 1) were not different from the others researchers who obtained similar values to volume, motility and strengh (Morais et al. 1994, Canisso et al. 2009, Canisso et al. 2011, Rota et al. 2012 and Madison et al. 2013).The minimum requirement for fresh semen motility prior to freezing is above $60 \%$, because after freezing and thawing a reduction of $30 \%$ to $40 \%$ in total motility values of fresh semen, and the minimal post thawed motility must be at least 30\% (CBRA 2013).

The sperm concentration can be variable according to the age, season, frequenccy of semen collection or natural covering, different methods of semen collection, sexual stimulation, testicular size and sperm production capacity per testicular mass (Brito et al. 2016). For this reason our value $\left(317.9 \pm 26 \times 10^{6}\right.$ spermatozoa $\left./ \mathrm{mL}\right)$ was less than reported by Morais et al. (1994) $\left(444.1 \pm 182,7 \times 10^{6} \mathrm{sperm} / \mathrm{mL}\right)$, but significantly higher when compared to the values found by Rota et al. (2010), Canisso et al. (2010) and Gloria et al. (201 1), 189.5 $\pm 22,9 \times 10^{6}$ spermatozoa/mL; $187.7 \pm 89,8 \times 10^{6}$ spermatozoa $/ \mathrm{mL} ; 253.0 \pm 91,2 \times 10^{6}$; and $266 \pm 67.2 \times 10^{6}$ spermatozoa $/ \mathrm{mL}$, respectively.

In respect of sperm morphology, the average of major and minor defects found (Table 1) was higher compared to values reported by Canisso et al. (2009, 2011), Morais et al. (1994), who found a mean of $(7.0 \pm 3.0 \%),(8.5 \pm 2.1 \%)$ for major defects, and $(7.0 \pm 4.0 \%)$ and $(7.0 \pm 2.6 \%)$ for minor defects respectively. This can be explained by the small number of animals that the cited authors have worked with.

In view of the computerized analysis of sperm movement characteristics (CASA) (Table 2), there was no difference in relation to total motility, straightness, amplitude of lateral head and beat cross frequency, for the data already reported in literature for these species. But the progressive motility values (PROGMOT); linearity (LIN); average path velocity (VAP); progressive linear velocity (VSL) and curvilinear velocity (VCL) were lower than those reported by Sabatini et al. (2014) being $40.1 \pm 8.8 \%$ PROGMOT; $110.0 \pm 7.2$ VAP; $100.4 \pm 6.3 \mathrm{VSL}$ and $160.8 \pm 13 \mathrm{VCL}$ (Table 2).

The average value of acrosome membrane integrity measured by fluorescence probes was lower than that reported in the literature for donkeys, an average of $44.5 \%$ (Sabatini et al. 2014). However, it is important to note that the average of alive sperm without acrosome reaction was similar to plasm membrane integrity. This is important, since to occur fertilization is essential a sperm with plasma and acrosome membrane integrity.

Nevertheless, even though the potential fertility of semen is difficult to predict accurately on the basis of a single assay, we agree with the statement of Neild et al. (2000) that the development of simple, inexpensive, more comprehensive assays that cover different sperm functions continues to be of interest. In this way, unlike to what is necessary to perform the evaluation with fluorescence probes, hypo-osmotic test requi- 
res fewer materials and can be quickly accomplished in field, demanding only a phase contrast microscope.

\section{Conclusion}

Since sperm motility is one of the key parameters to evaluate frozen semen quality, hypo-osmotic test and supra vital staining can be considered good predictive indicators in raw semen for donkey semen freezability. Hypo-osmotic test when compared to membrane integrity tests assessed by fluorescent probe has the same accuracy when used in evaluation of donkeys' semen. Therefore, should be used routinely, since it is a low cost and fast assay, fast and only needs a phase-contrast microscope.

\section{Acknowledgements}

Santa Luzia Farm, the veterinarian Carlos Augusto Salvagni to provide the animals and accommodation and all support of farm's employees.

\section{Animal welfare statement}

The study was approved by the Animal Use Ethics Committee, Biological Sciences, University of Brasília, Distrito Federal, Brazil (protocol no. 46029/2014).

\section{References}

Amann R. P., Picket B. W. (1987) Principles of cryopreservation and a review of cryopreservation of stallion spermatozoa. J. Equine Vet. Sci. 7, 145-173

Brito L. F. C., Barth A. D., Bilodeau-Goeseels S., Panich P. L., Kastelic J. P. (2003) Comparison of methods to evaluate the plasmalemma of bovine sperm and their relationship with in vitro fertilization rate. Theriogenology 60, 1539-1551

Brito L. F. C., Althouse G. C., Aurich C., Chenoweth P. J., Eilts B. E., Love C. C., Luvoni G. C., Mitchell J. R., Peter A. T., Pugh D. G., Waberski D. (2016) Andrology laboratory review: Evaluation of sperm concentration. Theriogenology 85, 1507-1527

Canisso I. F., Carvalho G. R., Silva E. C., Rodrigues A. L., Ker P. G., Guimarães J. D. (2009) Alguns aspectos biométricos do aparelho genital externo de jumentos doadores de sêmen da raça Pêga. Ciênc. Rural 39, 2556-2562

Canisso I. F., Carvalho G. R., Davies Morel M. C. G., Guimarães J. D., Mcdonnelld S. M. (2010) Sexual behavior and ejaculate characteristics in Pêga donkeys (Equus asinus) mounting estrous horse mares (Equus caballus). Theriogenology 73, 56-6

Canisso I. F., Carvalho G. R., Morel M. D., Ker P. G., Rodrigues A. L., Silva E. C. (2011) Seminal parameters and field fertility of cryopreserved donkey jack semen after insemination of horse mares. Equine Vet. J. 43, 179-183

CBRA, Colégio Brasileiro de Reproducao Animal (2013) Manual para exame andrológico e avaliação de sêmen animal: manual de orientação. 3.ed. Belo Horizonte: Colégio Brasileiro de Reprodução Animal, 104

Chalah T., Brillard J. P. (1998) Comparison of assessment of fowl sperm viability by eosin-nigrosin and dual fluorescence (SYBR14/PI). Theriogenology 50, 487-93

Dott H. M., Foster G. C. (1972) A technique for studying the morphology of mammalian spermatozoa which are eosinophilic in a differential live/dead stain. J. Reprod. Fertil 29, 443-445
Flores E., Taberner E., Rivera M.M., Peña A., Rigau T., Miró J., Rodríguez-Gil J. E. (2008) Effects of freezing/thawing on motile sperm subpopulations of boar and donkey ejaculates. Theriogenology 70, 936-945

Gloria A., Contri A., De Amicis I., Robbe D., Carluccio A. (2011) Differences between epididymal and ejaculated sperm characteristics in donkey. Anim. Reprod. Sci. 128, 117-122

Gundogan M., Yeni D., Avdatek F., Fidan A. F. (2010) Influence of sperm concentration on the motility, morphology, membrane and DNA integrity along with oxidative stress parameters of ram sperm during liquid storage. Anim. Reprod. Sci. 122, $200-$ 207

Harrison R. A. P., Vickers S. E. (1990). Use of fluorescent probes to assess membrana integrity in mammalian spermatozoa. J. Reprod. Fertil. 88, 343-352

Jeyendran R. S., Van der Ven H. H., Perez-Pelaez M., Crabo B. G., Zaneveld L. J. D. (1984) Development of an assay to assess the functional integrity of the human sperm membrane and its relationship to other semen characteristics. J. Reprod. Fertil. 70, 219-228

Klinc P., Rath D. (2007). Reduction of oxidative stress in bovine spermatozoa during flow cytometric sorting. Reprod. Domest. Anim 42, 63-67

Madison R. J., Evans L. E., Youngs C. R. (2013) The Effect of 2hydroxypropyl-b-cyclodextrin on post-thaw parameters of cryopreserved jack and stallion semen. J. Equine Vet. Sci 33, 272-278

Melo M. I. V., Henry M. (1999) Teste hiposmótico na avaliação do sêmen equino. Arq. Bras. de Med. Vet. Zootec 51, 71-78

Merkies K., Chenier T., Plante C., Buhr M. M. (2000) Assessment of stallion spermatozoa viability by flow cytometry and light microscope analysis. Theriogenology 54, 1215-1224

Morais R. N., Mucciolo R. G., Viana W. G. (1994) Biologia reprodutiva de jumentos. II. Características físicas e morfológicas do sêmen. Braz. J. Vet. Res. Anim. Sci 31, 49-57

Neild D. M., Chaves M. G., Flores M., Mora N., Beconi M., Agüero A. (1999) Hypoosmotic test in equine spermatozoa. Theriogenology 51, 721-727

Neild D. M., Chaves M. G., Flores M., Miragaya M. H., Gonzalez E., Agüero A. (2000) The HOS test and its relationship to fertility in the stallion. Andrologia 32, 351-355

Oldenhof H., Heutelbeck A., Blässe A. K., Bollwein H., Martinsson G., Wolkers W. F., Sieme H. (2015) Tolerance of spermatozoa to hypotonic stress: role of membrane fluidity and correlation with cryosurvival. Reprod. Fertil. Dev 27, 285-293

Oliveira J. V., Oliveira P. V. L. F., Oña C. M., Guasti P. N., Monteiro G. A., Silva Y. F. R. S., Papa P. M., Alvarenga M. A., Dell'Aqua Junior J. A., Papa F. O. (2016) Strategies to improve the fertility of fresh and frozen donkey semen. Theriogenology 85, 1267 1273

Rota A., Bastianacci V., Magelli C., Panzani D., Camillo F. (2010) Evaluation of plasma membrane integrity of donkey spermatozoa. Reprod. Domest. Anim 45, 228-232

Rota A., Panzani D., Sabatini C., Camillo F. (2012) Donkey jack (Equus asinus) semen cryopreservation: Studies of seminal parameters, post breeding inflammatory response, and fertility in donkey Jennies. Theriogenology 78, 1846-1854

Sabatini C., Mari G., Mislei B., Love C. C., Panzani D., Camillo F. (2014) Chromatin effect of post-thaw addition of seminal plasma on motility, viability and integrity of cryopreserved donkey jack (Equus asinus) spermatozoa. Reprod. Domest. Anim 49, 989-994

Vidament M., Dupere A. M., Julienne P., Evain A., Nove P., Palmer E. (1997). Equine frozen semen, freezability and fertility field results. Theriogenology 48, 907-917

Vidament M., Cognard E., Yvon J. M., Sattler M., Palmer E., Magistrini M. (1998) Evaluation of stallion semen before and after freezing. Reprod. Domest. Anim 33, 271-277

Vidament M., Vincent P., Martin F. X., Magistrini M., Blesbois E. (2009) Differences in ability of jennies and mares to conceive with cooled and frozen semen containing glycerol or not. Anim. Reprod. Sci 112, 22-35 
Erweiterte Zusammenfassung

\section{Evaluierung des Hypoosmotischen Schwelltests und der Eosin-Negrosin Supravitalfärbung als Indikatoren für die Tiefgefriertauglichkeit von Eselsamen}

In Brasilien besteht großes Interesse, Eselhengste für die Produktion von Hybriden (Maultieren) zu nutzen, die vor allem in großen Rinderfarmen Verwendung finden oder sogar zur Freizeitaktivität genutzł werden. Eine der beliebtesten Eselrassen für diese Kreuzung ist der Pêga-Esel, da er seinen Nachkommen Gelehrigkeit und gute Gänge weitervererbt. Allerdings hat die Kryokonservierung von Eselsamen, wie auch die einiger anderer Haussäugetieren, noch nicht den allgemein zufriedenstellenden Standard wie zum Beispiel beim Rind garantiert. Darüberhinaus ist die Anzahl der Studien über Tiefgefriersamen beim Esel sehr klein. Daher werden meist die Protokolle für das Pferd als Standard verwendet, da es der unter den Haustieren nächste Verwandte und darüber hinaus eine sehr gut erforschte Species ist. Die Kryokonservierung verursacht Schädigungen der Plasmamembran, die in Veränderung der Phospholipidzusammensetzung und der Membranpermeabilität resultiert. Deshalb ist es notwendig Methoden einzuführen, die es ermöglichen, schon im Nativsamen auf die Qualität nach dem Auftauen schließen zu können. Dies gilt etwa für die Gesamtmotilität und Indikatoren, welche die Plasmamembranintegrität bewerten. Unter diesen Techniken gibt es zwei kostengünstige und bequem auszuführende: den hypoosmotischen Schwelltest (HOST) und die Supravitalfärbung mittels Eosin-Nigrosin (Lebend/Tot). Vitalfärbungen werden verwendet um einen physikalischen Schädigung der Membranen festzustellen, der hypoosmotischen Schwelltest hingegen um die biochemische Funktionalität der Membranen zu testen. Der hypoosmotischen Schwelltest evaluiert also die funktionale Integrität der Plasmamembran. Spermien werden dazu in eine hypo-osmotische Lösung verbracht. Wegen der Unterschiede in der Osmolarität dringt solange Wasser in die Zellen ein bis ein osmotisches Gleichgewicht mit dem äußeren Medium hergestellt ist. Der Wassereinstrom erhöht das Volumen der Spermien was zu einem Anschwellen der Membranen führt. Die Plasmamembran des Spermienschwanzes, die bekannter Weise besonder sensitiv auf diesen Test reagiert, wird aufgrund des erhöhten Wassergehaltes ebenfalls anschwellen. Wenn diese Reaktion abläuft, dann ist die Plasmamembran intakt.

Zwanzig Ejakulate wurden in Plastikflaschen aufgefangen und sofort via Nylonfilter abgefiltert um eine schleimfreie Samen zu erhalten. Nur Ejakulate, die mehr als 60\% Beweglichkeit aufgewiesen haben wurden für das Tiefgefrieren verwendet. Volumen, Aussehen (Farbe und Konsistenz), Konzentration, Gesamtbeweglichkeit, Morphologie sowie die Überlebensfähigkeit der Samenzellen (Supravitalfärbung mittels EosinNigrosin-EN) und die Plasmamembranintegrität (Hypoosmotischer Schwelltest HOST) wurden im nativen Samen bewertet. Nach der Gewinnung und Analyse wurde die samenreiche, schleimfreie Fraktion 1:1 mit Magermilch-Glucose Verdünner verdünnt. Danach wurden die Proben zentrifugiert und die Samenpellets mit einem Gefrierverdünner auf eine Konzentration von $50 \times 10^{6}$ Zellen $/ \mathrm{ml}$ resuspendiert. Aliquote wurden in 0,5 $\mathrm{ml}$ Normal pailletten verpackt und auf einer Ablage 20 Minuten bei $5{ }^{\circ} \mathrm{C}$ im Eiskasten inkubiert. Danach wurden die Normalpailletten für 20 Minuten $6 \mathrm{~cm}$ über der Oberfläche des flüssigen Stickstoffes in einer Styroporbox inkubiert und danach in den flüssigen Stickstoff getaucht und im Stikkstoffcontainer gelagert. Die Analyse des aufgetauten Samens bestand aus computerunterstützter Analyse der charakteristischen Samenbeweglichkeitsparameter, Ermittlung der Samenüberlebensfähigkeit (EN), Ermittlung der Plasmamembranintegrität (HOST und Fluoreszenzsonden) sowie der Bestimmung der Akrosommembranintegrität mittels Fluoreszenzsonde.

Die für Nativsamen erhaltenen Werte (Volumen, Gesamtbeweglichkeit, Stärke, Überlebensfähigkeit (EN), Plasmamembranintegrität (HOST) und die Spermienmorphologie) sind in Tabelle 1 zusammengefasst. Für Nativsamen wurden folgende Werte erhoben: Gesamtbeweglichkeit $(81.0 \pm 13.2 \%)$; EN $(84.7 \pm 9.9 \%)$ and HOST $(54.9 \pm 23.3 \%)$. Die durchschnittliche Spermienkonzentration war $317.9 \pm 26 \times 10^{6}$ Spermien $/ \mathrm{mL}$. Die Resultate der computerunterstützten Analyse der Samenbeweglichkeitscharakteristika (CASA) sind in Tabelle 2 aufgeführt mit einer Totalbeweglichkeit von $50.4 \pm 22.7$ und einer progressiven Beweglichkeit von 12.2 \pm 8.1 .

Die Korrelationsanalyse zwischen Hypoosmotischem Schwelltest und Eosin-Nigrosin-Färbung ausgeführt im Nativsamen einerseits mit der Gesamtbeweglichkeit, Plasmamembranund Akrosomenmembranintegrität ermittelt mittels Fluoreszenzsonden im aufgetauten Samen auf der anderen Seite ist in Tabelle 3 abgebildet. Es wurde eine hohe Korrelation zwischen EN $(0,93)$ und HOST $(0,69)$ gemessen im Frischsamen einerseits in Vergleich zur Gesamtbeweglichkeit gemessen im aufgetauten Samen andererseits bestimmt. Niedrige Korrelationen wurden für EN und HOST gemessen im Frischsamen im Vergleich zur Plasmamembran- und Akrosomenmembranintegrität bestimmt im aufgetauten Samen erhalten.

Als die drei Methoden zur Bestimmung der Plasmamembranintegrität (EN, HOST und fluoreszierende Sonde mit CFDA) nach dem Auftauen verglichen wurden, stellte sich heraus, dass zwischen HOST und CFDA/PI kein Unterschied bestand $(P>0,05)$, was bedeutet, dass HOST zur Bestimmung der Plasmamembranintegrität dieselbe Genauigkeit wie die Fluoreszenzsonden hat (Tabelle 4). Bei den aufgetauten Samenproben wurde die Plasmamembranintegrität mittels CFDA/PI mit $32.2 \pm 13.7 \%$ und die Akrosomenmembranintegrität mit $30.1 \pm 14.8 \%$ ermittelt.

Wenn auch die mögliche Befruchtungsfähigkeit einer Samendosis noch nicht aufgrund des Ergebnisses einer einzelnen Methode vorherzusagen ist, erscheint die Entwicklung einfacher, kostengünstiger und umfassenderer Tests, die gleichzeitig mehrere Samenfuktionen erfassen können, wichtig. In dieser Hinsicht benötigt der Hypoosmotische Schwelltest wenig Material und kann schnell unter Feldbedingungen durchgeführt werden, wobei nur ein Phasenkontrastmikroskop notwendig ist.

Da die Samenmotilität ein Schlüsselparameter für die Beurteilung der Qualität von Tiefgefriersamen ist, können auch der Hypoosmotische Schwelltest und die Supravitalfärbung als gute vorhersagende Indikatoren für die Einfrierbarkeit von Eselsamen gewertet werden.

Schlüsselwörter: Sperma, Kryokonservierung, Pêga-Esel, Plasmamembranintegrität, Eosin-Nigrosin, Reproduktion, Besamung 